\title{
Flying Phobia
}

National Cancer Institute

\section{Source}

National Cancer Institute. Flying Phobia. NCI Thesaurus. Code C35413.

An overwhelming, irrational, and persistent fear of traveling in an aircraft. 